\title{
Training in the Mental Health Act: see one, do one, teach one?
}

\author{
Judy Harrison
}

In confrast to other professtonal groups, psychiatrists currently recelve litile formal training in the use of the Mental Health Act (MHA). This article describes a locally organised training day for senior registrars and reports on their previous experiences and future training needs in the use of the MHA.

The 1983 Mental Health Act is a complex piece of legislation, whose interpretation is constantly being revised by case law and periodic directives from the Department of Health. In order to become approved in the use of the Act, social workers must undergo a minimum of 60 days training in the MHA, including 20 days formal teaching and a competency-based assessment (Central Council for Education and Training in Social Work, 1993). Solicitors also now specialise in mental health law and have a professional journal devoted to it. However, psychiatrists can become Section 12 approved on submission of a written application to their Regional Health Authority. Factual knowledge of the MHA is included in the membership examination but tends to be restricted to its broad provisions and is taken at a time when trainees have little practical experience of using the Act.

The College is currently reviewing this situation (Caldicott \& Mann, 1994) and seems likely to recommend a more formal training process, which may incorporate MHA training as part of Continued Professional Development. In the interim, we report on a training day organised locally by senior registrars in the North West Region. The speaker invited was Rolf Olsen, Emeritus Professor of social policy, previously Vice-Chairman of the MHA Commission and a national and international expert in the field of mental health law.

\section{The training course}

At the start of the day, a simple questionnaire was used for senior registrars to describe any previous training in the MHA and suggest what form of training would be most helpful to them. They were also asked to rate their current level of confidence in interpreting and using the Act on a visual analogue scale of 0 to 10 .
Thirty-one trainees attended, with an even distribution according to year of training. Overall, only $12(39 \%)$ trainees said they had previously received individual supervision in the use of the Act from a consultant, $12(39 \%)$ had attended audit meetings relating to use of the Act and 15 (48\%) had received some formal training about the MHA. Of these 15, however, 12 cited training received as part of a membership course and only three had attended other forms of training. For the group as a whole the median confidence score was 5 with a range of 2 to 8 (Table 1).

All 31 trainees thought that psychiatrists should receive more training in the MHA than they do at present. There was considerable agreement about the sort of training needed: 25 trainees spontaneously suggested small group or workshop teaching with the opportunity to discuss real life situations. Seven specifically requested multidisciplinary teaching, particularly with social workers.

The day was broadly divided into two halves. In the first part, the speaker challenged many of our existing practices and forced us to examine our own attitudes to the use of the MHA. This was achieved through a mixture of statistical and anecdotal evidence and examples of recent litigation and press coverage. Ignorance of the law was

Table 1. Exposure to previous training and confidence in use of Act by year of training

\begin{tabular}{|c|c|c|c|c|}
\hline Training recelved & $\begin{array}{l}\text { Year } 1 \\
(n=11)\end{array}$ & $\begin{array}{l}\text { Year } 2 \\
(n-9)\end{array}$ & $\begin{array}{l}\text { Year 3/4 } \\
(n=11)\end{array}$ & $\begin{array}{l}\text { Total } \\
(n-31)\end{array}$ \\
\hline $\begin{array}{l}\text { Individual con- } \\
\text { sultant super- } \\
\text { vision }\end{array}$ & $3(27 \%)$ & $3(33 \%)$ & $6(54 \%)$ & 12 (39\%) \\
\hline $\begin{array}{l}\text { Attendance of } \\
\text { audit meetings }\end{array}$ & $4(36 \%)$ & $2(22 \%)$ & $6(54 \%)$ & 12 (39\%) \\
\hline $\begin{array}{l}\text { Formal training } \\
\text { One or more of } \\
\text { the above }\end{array}$ & $\begin{array}{l}4(36 \%) \\
5(46 \%)\end{array}$ & $\begin{array}{l}4(44 \%) \\
7(78 \%)\end{array}$ & $\begin{array}{l}7 \text { (64\%) } \\
8 \text { (73\%) }\end{array}$ & $\begin{array}{l}15(48 \%) \\
20(65 \%)\end{array}$ \\
\hline $\begin{array}{l}\text { Median conft- } \\
\text { dence score } \\
\text { (and range) }\end{array}$ & $5(2-8)$ & $5(3-7)$ & $7(4-8)$ & $5(2-8)$ \\
\hline
\end{tabular}

1. 12 trainees identified the membership course as a source of formal training; only 3 trainees had recelved formal training in addition to this 
clearly shown to be no excuse and identified as a frequent cause of litigation. The growing voice of consumerism was emphasised and we were encouraged to work with users to lobby for more resources rather than react defensively.

During the afternoon session, more practical issues arising from the Act were covered, with particular emphasis on consent to treatment. The issues generated so much interest that the teabreak was abandoned as trainees vied with one another to share their own experiences and seek advicel It was clear at the end of the day that there was ample material still to be covered for further training days.

\section{Comment}

The powers invested in psychiatrists by the 1983 Mental Health Act carry with them considerable responstbility and must be exercised in a manner which is above reproach (Eastman, 1994). Such standards are more likely to be achieved with specific ongoing training for those using the Act.

Our experience suggests that senior registrars do not presently receive sufficient training of this kind and would welcome the opportunity for greater discussion of the difficulties encountered in day to day use of the Act. More senior psychiatrists may suggest that competence in using the MHA increases with clinical experience but this is not necessarily so. In many services, areas of bad practice are only highlighted by visits from the MHA Commission or through patient complaints or litigation.

The senior registrars in the North West Region value the opportunity to organise their own training events and are planning further MHA training. It would seem timely, however, for psychiatrists as a whole to take a more rigorous approach to their own training needs in the use of the Mental Health Act.

\section{Training contact address}

Professor Olsen can be contacted regarding training events at: The Bothy, 23 George Rd, Edgbaston, Birmingham B15 IPJ

\section{References}

CALDICOTT, F. \& MANN, S. (1994) Mental health law: college committed to improving training. Brttish Medical Journal, 308, 408-409.

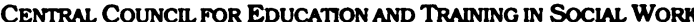
(1993) Regulations and Guidance for the Trating of Social Workers to be Considered for Approval in England and Wales under the Mental Health Act 1983.

EASTMAN, N. (1994) Mental health law: ctvil liberties and the principle of reciprocity. British Medical Joumal, $\mathbf{3 0 8}$. 43-45.

Judy Harrison, Consultant Psychiatrist, Manchester Royal Infirmary, Oxford Rd, Manchester M13 9WL (formerly Lecturer, University of Manchester Department of Community Psychiatry, Royal Preston Hospitall 